\title{
Comparative analysis of environmentally friendly materials
}

Lidiya Girya*, Elena Vinogradova, Alina Gondusova, Telman Muradov, and Aleksey Horoshilov

Don State Technical University, 344022, Rostov-on-Don, Russia

\begin{abstract}
Woodworking industry currently generates a large amount of unused waste suitable for recycling. The solution to this urgent problem is the use of this raw material in construction industry, which would solve many economic and environmental problems. The article describes the main technologies for the construction of residential houses from wood concrete blocks and the features of the construction and operation of such buildings. Methods of comparative analysis of the structure of wood concrete and brick housing construction and the possibility of ecological materials' effective use in the conditions of the Rostov region on the basis of thermal engineering calculation are also presented. Having analyzed the main characteristics and properties of ecological building material, the main advantages and disadvantages of wood concrete in the construction and further operation of residential buildings are considered.
\end{abstract}

\section{Introduction}

The history of cement-wood material development begins in the 50s of the 20th century in the United States of America. The emergence of wood concrete is due to a significant reduction in household incomes and a decrease in demand in the residential real estate market. Low cost and good indicators of strength and thermal insulation formed the basis of the most significant requirements for a building material. The rapid development of the cement-wood composition contributed to the beginning of its production on an industrial scale. In 1960, the Soviet Union standardized wood concrete and began mass production and further use of the material in the construction of buildings and structures. Despite the excellent properties, in the 90 s the wood-concrete factories were destroyed and production was discontinued. But the structures built in Soviet times from cement-wood material have survived today and have not lost their original qualities 10 .

During the construction of a residential building, two production technologies are possible: wood concrete blocks and monolithic production of structures with wood concrete. The first method is carried out by arranging masonry from wood concrete and cement-sand mortar. For a binder solution, it is possible to use both the classical composition (the ratio of cement and sand 1: 3), and the use of any adhesive intended for blocks. The material is easily amenable to manual or mechanized processing, so its installation on the construction site is greatly facilitated 3 . It should be noted that the 3 rd or

\footnotetext{
*Corresponding author: giryalida@yandex.ru
} 
4th row is strengthened with the help of reinforcement laid under the cement-sand mortar layer throughout the entire masonry. Wood fiber concrete device corresponds to the technology of installing bricks or cinder blocks. The laying of the external walls begins from the corners of the house under construction, using a hydraulic level, a plumb line and a cord. These tools allow laying with special precision. It is necessary to ensure that the mortar has the correct consistency in order for the blocks to displace excess mixture with their mass. Construction is carried out at a temperature not exceeding $10^{\circ} \mathrm{C} 4$.

Particular attention should be paid to the junction of the ceiling to the outer wall. To evenly distribute the load, it is necessary to support the distribution armored belt, thanks to this design, the wood fiber concrete blocks will not deform at the points of contact with the slabs or floor beams. When arranging walls for pouring an armored belt, it is possible to use ready-made special blocks - armored blocks.

The second method of erecting walls from wood fiber concrete is monolithic production of structures with wood concrete. This technology involves the use of fixed formwork with subsequent pouring of wood concrete mortar. With the help of a cord stretched along the axis of the base, the formwork panels are mounted. Then the prepared solution is placed in a fixed and tamped formwork in the layers, the thickness of which is not more than $20 \mathrm{~cm}$. The pouring of the mortar continues until the entire formwork box is filled. The solution is covered with a hardening film. The next day, the process is repeated until the wall reaches the design parameters 5 .

GOST 19222-2019 establishes technical requirements for wood concrete products. According to the standard, the composition of the wood-concrete mixture should consist of several components: organic filler, cement binder, water and components of chemical origin.

\section{Methods}

The article presents two methods of comparative analysis, which make it possible to determine the most profitable building material for the construction of the outer walls of a two-story residential cottage. The construction site is a land plot located in Rostov-on-Don. In the process of the analysis, the main building materials will be wood concrete blocks and ordinary clay bricks (refer with Fig. 1).

The first method consists in carrying out a heat engineering calculation of the enclosing structure made of wood concrete material (refer with fig. 1, a). In the process of calculations, the necessary values of the climatic characteristics of the Rostov region were used, which correspond to the indicators given in BC 131.13330.2012 "Construction climatology". The required standards, which determine favorable conditions for living in a residential building, do not contradict the data presented in BC 50.13330.2012 "Thermal protection of buildings" 6 .

The first step in the calculation is to calculate the degree-day during the heating period:

$$
D_{d}=\left(t_{i n}-t_{h t}\right) \cdot z_{h t}=(20+0.6) \cdot 171=3522.6^{\circ} \mathrm{C} \cdot d a y,
$$

where $t_{i n}$ is air temperature inside the dwelling in winter $\left({ }^{\circ} \mathrm{C}\right) ; t_{h t}$ is an average outdoor temperature during the cold season $\left({ }^{\circ} \mathrm{C}\right) ; z_{h t}$ is duration of the heating period (day).

The normalized value of the heat transfer resistance of the wall under study should also be calculated:

$$
R_{\text {reg }}=a \cdot D_{d}+b=0.00035 \cdot 3522.6+1.4=2.63 \mathrm{~m}^{2} \cdot{ }^{\circ} \mathrm{C} / W,
$$


where $a$ and $b$ are the coefficients that correspond to the values given in regulatory documents.
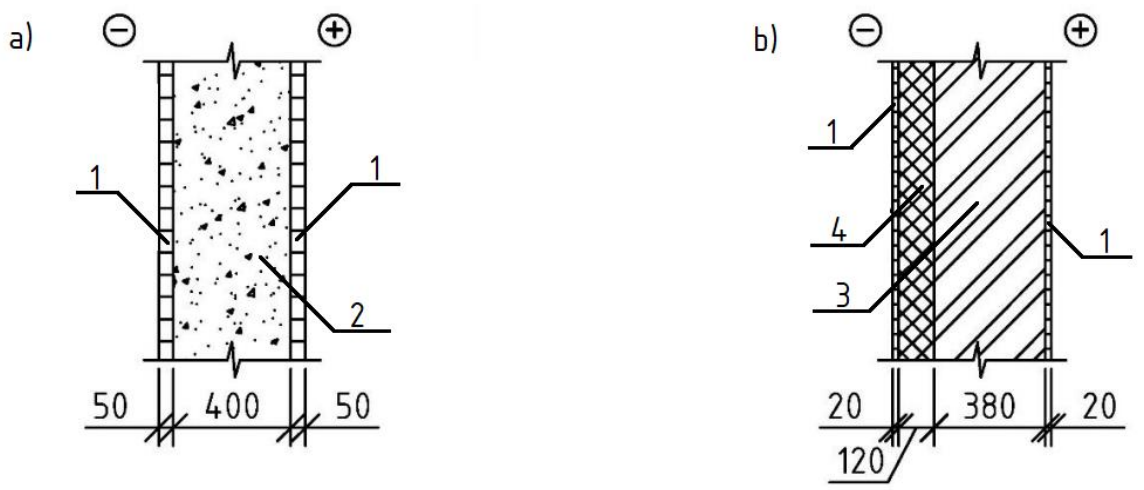

Fig. 1. Structural schemes of external walls: $a$ - wood fiber concrete block device: 1 - lime-sand plaster, 2 - wood fiber concrete block; $b$ - device made of clay ordinary brick: 3 - ordinary clay brick on a cement-sand base, $4-$ mineral wool

Equality of total thermal (R0) and standardized $\left(R_{\text {reg }}\right)$ resistance is the basis for heat engineering calculation of enclosing structures:

$$
R_{0}=R_{\text {reg }}
$$

Based on this equality, the required resistance of the outer wall, erected from wood concrete blocks, which are plastered from the outside and inside, has been calculated:

$$
\begin{aligned}
R_{t r}=R_{\text {reg }}-R_{\text {in }}-R_{\text {ex }} & =R_{\text {reg }}-\frac{1}{a_{\text {in }}}-\frac{1}{a_{e x}}=2.63-\frac{1}{8.7}-\frac{1}{23}= \\
& =2.47 \mathrm{~m}^{2} \cdot{ }^{\circ} \mathrm{C} / \mathrm{W},
\end{aligned}
$$

where $a_{\text {in }}$ is an internal surface heat transfer coefficient $\left(W / m^{2} \cdot{ }^{\circ} \mathrm{C}\right) ; a_{e x}$ is an external surface heat transfer coefficient $\left(W / \mathrm{m}^{2} \cdot{ }^{\circ} \mathrm{C}\right)$.

The next step is to calculate thermal resistance of wood concrete blocks (insulation):

$$
R_{a}=R_{t r}-\sum R_{i}=R_{t r}-\sum \frac{\delta_{i}}{\lambda_{i}}=2.47-\frac{0.05}{0.7}-\frac{0.05}{0.7}=2.33 \mathrm{~m}^{2} \cdot{ }^{\circ} \mathrm{C} / \mathrm{W}
$$

where $\sum R_{i}$ is the sum of all layers' resistance of the wall without insulation $\left(\mathrm{m}^{2} \cdot{ }^{\circ} \mathrm{C} /\right.$ $W) ; \delta_{i}$ is the thickness of the $i$-s layer (m); $\lambda_{i}$ is the coefficient of thermal conductivity of the $i$-s material $\left(W / m^{2} \cdot{ }^{\circ} \mathrm{C}\right)$.

This is followed by the calculation of the wood concrete blocks thickness (insulation):

$$
\delta_{\mathrm{a}}=\lambda_{\mathrm{a}} \cdot R_{\mathrm{a}}=0.16 \cdot 2.33=0.37 \mathrm{~m} .
$$

The accepted thickness of wood concrete blocks is $400 \mathrm{~mm}$.

The final step is to calculate the thermal resistance of the wall structure from the condition that the total thickness of the wood concrete blocks is $400 \mathrm{~mm}$. 


$$
\begin{gathered}
R_{o}=R_{\text {in }}+R_{\text {ex }}+\sum_{i} R_{i}+R_{a}=\frac{1}{8.7}+\frac{1}{23}+\frac{0.05}{0.7}+\frac{0.05}{0.7}+\frac{0.4}{0.16}= \\
=2.8 m^{2} \cdot{ }^{\circ} \mathrm{C} / W>>2.63 \mathrm{~m}^{2} \cdot{ }^{\circ} \mathrm{C} / W
\end{gathered}
$$

When calculating the structure of the outer wall, it is worth paying attention to the fact that wood fiber concrete, due to its structure, has not only good strength characteristics, but also has high rates of sound and thermal insulation 5.

The enclosing structure made of ordinary bricks and mineral wool was chosen as the second analogue. The outer wall from the outer and inner surfaces is covered with decorative plaster (refer with fig. $3, \mathrm{~b}$ ).

The results of heat engineering calculations and the characteristics of each material are presented in Table 1.

\begin{tabular}{|c|c|c|c|c|c|c|}
\hline No & Structure name & $\begin{array}{c}\text { Density } \\
\boldsymbol{\rho}_{\mathbf{0}}, \\
{\left[\mathrm{kg} / \mathrm{m}^{3}\right]}\end{array}$ & $\begin{array}{l}\text { Thick- } \\
\text { ness } \\
\delta,[\mathrm{m}]\end{array}$ & $\begin{array}{c}\text { Thermal } \\
\text { conductivity } \\
\text { coefficient } \lambda \text {, } \\
{\left[\mathbf{W} / \mathbf{m}^{2} \cdot{ }^{\circ} \mathrm{C}\right]}\end{array}$ & $\begin{array}{l}\text { Heat transfer } \\
\text { resistance R, } \\
{\left[\mathbf{m}^{2} \cdot{ }^{\circ} \mathrm{C} / \mathbf{W}\right]}\end{array}$ & $\begin{array}{c}\text { Estimat } \\
\text { ed } \\
\text { insula- } \\
\text { tion } \\
\text { thick- } \\
\text { ness } \boldsymbol{\delta}_{\mathrm{y}} \text {, } \\
{[\mathrm{mm}]}\end{array}$ \\
\hline \multicolumn{7}{|c|}{ Masonry wall construction with a total thickness of $540 \mathrm{~mm}$} \\
\hline 1 & Lime-sand plaster & 1700 & 0.02 & 0.93 & 0.022 & \multirow[t]{4}{*}{119} \\
\hline 2 & $\begin{array}{l}\text { Ordinary clay } \\
\text { brick on a } \\
\text { cement-sand base }\end{array}$ & 1800 & 0.38 & 0.81 & 0.469 & \\
\hline 3 & Mineral wool & 200 & $\mathrm{x}$ & 0.03 & $\mathrm{x} / 0.03$ & \\
\hline 4 & Lime-sand plaster & 1700 & 0.02 & 0.93 & 0.022 & \\
\hline \multicolumn{7}{|c|}{ Wall structure made of wood concrete blocks with a total thickness of $500 \mathrm{~mm}$} \\
\hline 1 & Lime-sand plaster & 1700 & 0.05 & 0.7 & 0.071 & \multirow[t]{3}{*}{370} \\
\hline 2 & $\begin{array}{l}\text { Wood fiber } \\
\text { concrete blocks }\end{array}$ & 800 & $\mathrm{x}$ & 0.16 & $\mathrm{x} / 0.16$ & \\
\hline 3 & Lime-sand plaster & 1700 & 0.05 & 0.7 & 0.071 & \\
\hline
\end{tabular}

Table 1. Thermal and physical characteristics of materials and calculation results

The second method is a comparative analysis of the material consumption required for the construction of the outer walls of a two-story residential cottage. The house has the following parameters: the size of the building 10x12.26 m, floor height $\mathrm{H}=3 \mathrm{~m}$, total area of the object $\mathrm{S}=192.29 \mathrm{~m}^{2}$. Based on rules and regulations collection 8 "Structures of bricks and blocks", the required amount of clay ordinary brick and cement-sand mortar was determined (refer with table 2). According to the total volume of the enclosing structures and the volume of one block with the dimensions $40 \times 20 \times 50 \mathrm{~cm} 8$ calculation of the required consumption of wood concrete material has been performed.

Analysis requires calculating the following volume of the masonry:

$$
V=\left(F_{s a}-F_{o p}\right) \cdot \delta=(387.23-52.01) \cdot 0.38=127.38 \mathrm{~m}^{3},
$$

where $F_{s a}$ denotes the external enclosing surface area $\left(\mathrm{m}^{2}\right), F_{o p}$ is the sum of the areas of all residential building's openings $\left(\mathrm{m}^{2}\right), \delta$ is construction size, $\mathrm{m}$.

It should be noted that the norm of the required amount of ordinary bricks for $1 \mathrm{~m}^{3}$ masonry is 395 pcs., cement-sand mortar $-0.234 \mathrm{~m}^{3}$ respectively. The volume of the wood concrete block with the parameters $40 \times 20 \times 50 \mathrm{~cm}$ is $0.04 \mathrm{~m}^{3}$, mortar consumption is 2.5 times less when constructing the walls made of wood concrete, in contrast to brick 9 . 
Table 2. The required amount of material for the installation of enclosing structures

\begin{tabular}{|c|c|c|c|c|}
\hline \multirow[t]{2}{*}{ Wall material } & \multirow{2}{*}{$\begin{array}{c}\text { Wall } \\
\text { thickness, } \\
{[\mathrm{m}]}\end{array}$} & \multirow{2}{*}{$\begin{array}{c}\text { Wall } \\
\text { volume, } \\
{\left[\mathrm{m}^{3}\right]}\end{array}$} & \multicolumn{2}{|c|}{ Total material consumption } \\
\hline & & & $\begin{array}{c}\text { Bricks / Blocks, } \\
{[\mathrm{pcs}]}\end{array}$ & Mortar, $\left[\mathrm{m}^{3}\right]$ \\
\hline Brick & 0.38 & 127.38 & 50316 & 29.807 \\
\hline $\begin{array}{c}\text { Wood fiber } \\
\text { concrete blocks }\end{array}$ & 0.4 & 134.08 & 3352 & 11.823 \\
\hline
\end{tabular}

\section{Results}

The performed heat technical engineering calculation showed that wood concrete blocks used in the construction of residential low-rise buildings are not only a good structural material, but also have sufficient thermal insulation properties. The use of wood concrete makes it possible to reduce the cost of additional insulation.

Based on the results obtained, it becomes obvious that the required consumption of bricks (50 316 pieces) significantly exceeds the required number of wood concrete blocks (3 352 pieces). Thus, the construction of external walls made of wood concrete is the least labor-intensive process (in comparison with the implementation of brickwork, the arrangement of blocks involves significantly fewer operations). In addition, the woodconcrete material is lightweight, which makes it possible for the construction team to complete the work without using lifting equipment 10 .

\section{Discussion}

Analyzing the state of the issue under study, the data obtained made it possible to establish the positive and negative aspects of the residential buildings' construction from wood concrete blocks in the conditions of the Rostov region.

Advantages:

- Material's environmental friendliness. In the production of wood concrete, only safe components, that do not emit negatively affecting human health substances into atmosphere during construction and subsequent operation, are used;

- low thermal conductivity. The material has good thermal insulation properties, which helps to preserve the accumulated heat in the room;

- high bending strength. When the house settles, the material is able to deform, preventing cracking;

- density. Wood fiber concrete blocks have low density, on average equal to 600$650 \mathrm{~kg} / \mathrm{m}^{3}$. Due to this property of the material, the total weight of the house structure is significantly reduced, and the pressure on the foundation is reduced;

- $\quad$ soundproofing. The material has high sound absorption performance, superior to reinforced concrete and brick walls;

- fire safety. Wood fiber concrete blocks are practically non-combustible building materials. Chemical additives in its composition increase the refractoriness up to 3 hours, and the flame that is released when the blocks interact with fire will not emit corrosive smoke 14.

Disadvantages:

- changing the blocks' geometry. Finished products can vary greatly in size and configuration. This disadvantage forces builders to increase the thickness of the seams, which, in turn, leads to "cold joints" formation; 
- low strength. This material can be used for the construction of low-rise buildings or as insulation 17.

Another disadvantage of wood concrete is a high degree of moisture saturation. Building blocks can accumulate moisture, which in further operation leads to the destruction of the material. To avoid this, it is necessary to make high-quality waterproofing of the foundation and plaster the outside of the outer walls 18 .

\section{Conclusion}

The analysis of the results obtained showed that during the construction of residential buildings, the use of standard wood concrete blocks $(400-450 \mathrm{~mm})$ guarantees the achievement of the required indicators of thermal protection of the building without thermal insulation materials installation. Thus, wood concrete in the natural and climatic conditions of the Rostov region is an answer to traditional structural building materials.

Unlike small-piece materials, wood concrete blocks have large dimensions, which facilitates the process of installing blocks, and also, due to the reduction in the construction labor intensity, there is no need to hire workers with a high discharge 19.

The use of wood concrete material in the construction of a residential building contributes to the formation of an environmentally friendly and favorable environment for human life.

The technology for the construction of residential buildings from wood concrete is not widespread at the moment. The main reason is the termination of production in the $90 \mathrm{~s}$ on the territory of the Russian Federation. But, despite this, there has recently been an increase in demand for ecological building material 20.

\section{References}

1. The history of the emergence and development of wood concrete [Electronic resource]. Information on https://www.stroysprint.ru/articles/the-history-of-arbolit.html.

2. Performance-based selection of sustainable construction solutions for external walls Veludo, S., Rato, V. 2020 WIT Transactions on the Built Environment 193, Pp. 113124

3. Wood concrete house: construction technology. Warming, waterproofing, exterior decoration [Electronic resource]. Information on https://kblok.ru/blog/dom-iz-arbolitaosobennosti-stroitel\#sec-2

4. Wood fiber concrete: characteristics and purpose of building material [Electronic resource]. Information on https://stroy-podskazka.ru/arbolit/harakteristika/

5. Brick or Wood fiber concrete: which is better, cheaper, warmer [Electronic resource]. Information on https://kafmt.ru/teh-harakteristiki/kirpich-ili-arbolit-chto-luchshedeshevle-teplee.html

6. A. Estokova, A. Paulikova, E. Singovszka, Environmental Science and Engineering (2019) 97-105

7. S.G. Sheina, L.V. Girya, Engineering Bulletin of the Don 4 (2011). Information on http://ivdon.ru/magazine/archive/n4y2011/703 (free access) in Rus.

8. Natural conditions and natural resources of the Rostov region [Text], Rostov-on-Don, 2002. 
9. S.G. Sheina, L.V. Girya, A.S. Livitchuk, IOP Conference Series: Materials Science and Engineering 1083, 012105 (2021). Information on http://doi:10.1088/1757$899 \mathrm{X} / 1083 / 1 / 012105$

10. S.G. Sheina, L.V. Girya, E.V. Vinogradova, A. Sobolevskiy, IOP Conf. Series: Materials Science and Engineering 913, 042032 (2020). doi:10.1088/1757$899 X / 913 / 4 / 042032$

11. S.G. Sheina, V. Belash. V. Ulianskaia, Rating estimation of sustainability in construction of high-rise building, SPbWOSCT-2018, E3S, WoC 110, 01054 (2019). Information on https://doi.org/10.1051/e3sconf /2019

12. I.Yu. Zilberova, K.S. Petrov, Al Fatla Abdullah Neama Mohsen, IOP Conf. Series: Materials Science and Engineering 913, 042020 (2020). Information on http://doi:10.1088/1757-899X/913/4/042020

13. I.Yu. Zilberova, K.S. Petrov, Al Fatla Abdullah Neama Mohsen, IOP Conf. Series: Materials Science and Engineering 913, 042019 (2020). Information on http://doi:10.1088/1757-899X/913/4/042019

14. I. Yu. Zilberova, K.S. Petrov, M. Artsishevsky, IOP Conference Series: Materials Science and Engineering 753 (3) 042020. Information on http://doi: 10.1088/1757899X/753/4/042020

15. A.E. Akan, F. Ünal, F. Koçyiğit, International Journal of Thermophysics 42 (1), 4 (2021).

16. G. Kastiukas, X. Zhou, IOP Conference Series: Materials Science and Engineering. 660 (1), 012074 (2019).

17. T. Opher, M. Duhamel, I.D. Posen, (...), A. Anvari, H.L. MacLean, Journal of Cleaner Production 279, 123819 (2021).

18. A. Gupta, H. Thakur, Wood - concrete composite for thermally insulated building construction material 2018 ASME International Mechanical Engineering Congress and Exposition, Proceedings (IMECE) 6A-144113.

19. C. Galan-Marin, C. Rivera-Gomez, A. Garcia-Martinez, Operational and embodied energy assessment, Materials 9 (6), 465 (2016).

20. R. Chippagiri, H.R. Gavali, R.V. Ralegaonkar, (...), A. Shaw, A. Bras, Sustainability (Switzerland) 13 (3) 1195, 1-12 (2021). 